\title{
MERLEAU-PONTY E A FILOSOFIA DA NEGATIVIDADE EM O VISÍVEL E O INVISÍVEL
}

\author{
Adilson Xavier da Silva \\ Universidade Federal do Rio de Janeiro \\ achavier@uai.com.br
}

\begin{abstract}
Resumo: O artigo tem como objetivo descrever a crítica de Maurice Merleau-Ponty (19081961) sobre a Filosofia da negatividade, especialmente em sua obra $O$ visivel e o invisivel (1964) publicada após sua morte. Essa crítica é endereçada principalmente ao filósofo JeanPaul Sartre (1905-1980).
\end{abstract}

Palavras-chave: Reflexão, filosofia da negatividade, ontologia, dialética.

\section{INTRODUÇÃO}

A reflexão entre a relação do ser e do nada só encontra lugar no pensamento de sobrevôo, afirma Merleau-Ponty. Esse pensamento de sobrevôo quer descrever o nada como ser. Quer afirmar que o nada não é nada, mas uma certa condição do nada a ser, ou pelo menos a vir a ser objeto de alguma coisa, porque o nada está inscrito no ser. "O Ser tem necessidade do nada para vir ao mundo, e reciprocamente. Essa dupla relação define o Ser e ela não é suscetível de trabalho, de fecundidade, de mediação" (MerleauPONTY, 2000, p. 222).

Assim, as relações entre o ser e o nada não revelam quase nada, mas o objeto é, enquanto o ser e o nada são testemunho desse esvaziamento do ser no mundo. O homem está escrito nessa relação, seja como paixão vã ou paixão inútil (SARTRE, 1943, p. 708). A paixão, afirma Merleau-Ponty, é o retirar o véu das coisas como mero objeto, como coisificação de si mesmo, porque o homem é 
corroído pelo desejo do ser e tem nele mesmo a necessidade de preencher o vazio desse desejo inacabado. Mas o nada escorrega entre as mãos, não é compreendido em seu mistério. Essa paixão inútil é vã, porque jamais um "poderá vir a ser o outro" (MERLEAUPonTy, 2000, p. 222). Nesse sentido, o homem é sempre um fracasso. Não existe diferença entre beber alguma coisa qualquer e ser um político. $\mathrm{O}$ "sujeito engaja-se totalmente porque, sendo nada, precisa caminhar em direção ao mundo, onde tudo é interessante” (p. 223). O engajamento é imotivado e nunca é inteiramente efetivo porque, no fundo, não existe uma diferença entre uma reflexão filosófica que vincula o homem ao exterior e uma reflexão filosófica que o distingue por completo dessa vinculação, às vezes, desvelando o enigma do ser.

Portanto, a reflexão nunca é um mero regresso a um sujeito absoluto detentor das chaves do mundo; ela não possui os elementos constitutivos do objeto atual, como também não pode examiná-lo por todos os lados. Mas é preciso tomar consciência do mundo mediante um contato, mediante uma freqüentação que inicialmente excede os seus poderes de compreender as coisas, simplesmente, pela reflexão absoluta que temos sobre elas.

Desse modo, as razões jamais nos impelem a recusar a própria evidência perceptiva. E que ela, ao se confundir com as razões "que temos para devolver-lhe algum valor depois que foi abalada" (Merleau-Ponty, 1971, p. 58), nos força a admitir que a fé perceptiva "sempre foi resistência à dúvida, e o positivo, negação da negação" (p. 58). O pensamento reflexivo transforma o apelo ao interior como uma recusa aquém do mundo, conduz a fé no mundo para as coisas ditas como explicitação, que é uma "transformação sem retorno, repousa sobre si própria, sobre a fé perceptiva de que ela pretende nos dar o teor e a medida" (p. 58). Nesse caso, "creio no mundo e nas coisas que acredito na ordem e na conexão de meus pensamentos" (p. 58).

Esse pensamento reflexivo, fundado na abertura do mundo pela percepção, reivindica para si uma nova freqüentação ingênua 
do mundo e concebe de maneira diferente as noções do ser-sujeito e do próprio-ser no horizonte do mundo, onde, diante do filósofo, somos levados a dizer as "razões para acreditar que ele procura em si mesmo, em seus pensamentos, aquém do mundo" (MerleauPONTY, 1971, p. 58). Esse mesmo pensamento reflexivo busca o que querem dizer para nós as coisas, na sua abertura inicial de transcendente e, ao mesmo tempo, estranha de toda interioridade. Para que esse pensamento obtenha sua abertura é necessário esvaziar o ser-sujeito "de todos os fantasmas de que a filosofia o entulhou" (p. 59). É mister assegurar meu acesso às próprias coisas e, por conseguinte "purificar inteiramente a minha noção de subjetividade” (p. 59). No fundo - diz Merleau-Ponty - só há duas idéias da subjetividade. A primeira é a da subjetividade vazia, desligada, universal, e a outra a da subjetividade plena, insinuada no mundo. Sartre parte dessa idéia do nada que vem ao mundo, que o nada bebe o mundo, que o nada "precisa do mundo para ser o que quer seja, mesmo nada, e que, no sacrifício que de si mesma, faz ao ser, permanece estrangeiro ao mundo" (MerLeau-PonTy, 1962, p. 230).

Através dessa intuição do ser, como plenitude absoluta e absoluta possibilidade, Sartre pensa explicitar nosso acesso primordial às coisas "como uma ação impensável das coisas sobre nós" (MerLEAUPONTY, 1971, p. 59). No instante mesmo em que me concebo como negatividade e gero o mundo como possibilidade, não existe mais interação, "caminho eu próprio diante de um mundo maciço; entre ele e mim não há encontro nem fricção, portanto ele é o Ser e eu nada sou" (p. 59).

Assim, o que se diz do ser, do mesmo modo, se diz do nada, eles se identificam, são o "direito e o avesso do mesmo pensamento" (p. 60), pois somos e permanecemos inversos e confundidos, "precisamente porque não somos da mesma ordem" (p. 59).

Tratar de pensar o negativo como objeto de pensamento, ou simplesmente tentar dizer o que é, não é pensá-lo como negativo, mas "é fazer dele uma espécie de ser mais sutil ou delicado, é reintegrá-lo no ser" (p. 60). Ora só podemos pensar o negativo 
através do que ele não é, só podemos preservar sua pureza negativa na falta de ser, ou seja, a "falta que se constitui, a si própria, em falta, e, portanto, a fissura que se cava na exata medida em que se enche" (p. 60).

O nada - diz Merleau-Ponty - não existe. Para revelá-lo, devemos fazer uma espécie de nega-intuição. Ao articular o nada como nega-intuição, ele modifica o problema do cogito, do mesmo modo essa articulação afetará o problema do outro.

\section{A filosofia DA NEGATIVIDADE}

A filosofia da negatividade articula de tal maneira a oposição entre o eu e o mundo, mostrando que eu não sou nada, e o mundo é o ser, isto é, que "pensa como o-que-não-é- totalmente é também uma filosofia do ser” (Merleau-Ponty, 1971, p. 61). Para a filosofia da negatividade, o nada é o que não é senão o ser. $O$ nada não é "nem atributo, nem função, nem acidente do ser, mas não há senão o ser" (p. 61).

Essa articulação no sentido de uma filosofia negativista absoluta, que é também uma filosofia da possibilidade absoluta, decorre dos problemas de mistura ou união e

mistura e união são impossíveis entre o que é e o que não é, mas pela mesma razão que torna a mistura impossível, um não poderia ser pensado sem o outro [porque] no que sou de mais próprio, não sou nada, nunca nada me separa de mim mesmo, mas também não me assinala a mim mesmo e existo em ek-stase nas coisas. (Merleau-PonTy, 1971, p. 61-63)

Ao reconhecer o negativo por aquilo que é em relação a ele, praticamos uma nega-intuição, mas isso não quer dizer que temos de escolher entre o irrefletido e a reflexão; não quer dizer também que temos de escolher entre a fé perceptiva e a imanência de meus pensamentos com relação a mim mesmo que penso, pois "é a mesma coisa não ser nada e habitar o mundo" (p. 63). 
Entre o saber de si e o saber do mundo não há mais debate de prioridade, ainda que ideal; em particular, o mundo não está mais fundado sobre o eu penso, como o que está ligado sobre o que liga; o que sou, sou-o apenas à distância, ali, nesse corpo, nesse personagem, nesses pensamentos que empurro diante de mim e que são apenas os meus longes menos afastados; e, inversamente, este mundo que não sou eu, e ao qual me apego tão intensamente como a mim mesmo, não passa, em certo sentido, do prolongamento de meu corpo; tenho razões para dizer que eu sou o mundo. (Merleau-Ponty, 1971, p. 63)

Desse modo, a cãibra reflexionante e os idealismos embutidos na filosofia negativista desaparecem, "porque a relação de conhecimento se apóia sobre uma relação de ser” (p. 63). Dessa forma, "ser não significa permanecer na identidade, mas levar diante de mim o identificável” (p. 63), ou seja, o que há. De acordo com isso, não acrescento nada a "não ser o ínfimo redobramento tal como é” (p. 63). No entanto, assinala Merleau-Ponty, a passagem do ser bruto espírito selvagem é exigida do fundo do ser, no visível ao invisível, a simples negação radical de dizer o que eu sou desaparece e, ao mesmo tempo, pede para negar o seu próprio movimento ou nascimento no mundo.

Se for através da certeza da fé perceptiva que tenho acesso ao próprio mundo que os outros percebem, então, como se traduz essa certeza numa filosofia verdadeiramente negativista: "o que vejo não é meu no sentido de um mundo privado" (p. 64). Vejamos o exemplo da mesa:

A mesa é, de agora em diante, a mesa; até mesmo as visões perceptivas que tenho, e que estão ligadas à posição de meu corpo, fazem parte do ser e não de mim mesmo; até os aspectos da mesa, que estão ligadas à minha constituição psicofísica sua cor singular, se sou daltônico e a mesma pintada de vermelho -, fazem ainda parte do sistema do mundo. (MERLEAUPONTY, 1971, p. 64) 
Note-se que Merleau-Ponty quer comprovar que a percepção do mundo pelos outros não pode entrar em competição com aquela que tenho, pois "meu caso não se assimila ao dos outros, vivo minha percepção por dentro e, do interior, ela possui um poder incomparável de ontogênese" (p. 64). É através desse poder de ontogênese que descubro minha especialidade e minha diferença.

Agora sobre o manto da ontogênese estou no mundo, ou no mundo de uma vida privada, que coloca à prova meu devotamento ao ser, que revela ao pé da letra minha generosidade e que coloca minha intimidade para que "cumpra as promessas que fiz quando admiti que eu não era nada e que era ultrapassado pelo ser" (p. 65).

Permaneço, nesse sentido, como a única testemunha da ontogênese, "os outros nada podem acrescentar à evidência do ser para mim” (p. 65). Já acreditava, antes da intervenção deles, que o ser nada deve aos meus estados de consciência, "mas o nada que sou e o ser que vejo formavam, assim mesmo, uma esfera fechada" (p. 65). O olhar dos outros sobre as coisas "é o ser que reclama o que lhe é devido e que me incita a admitir que minha relação com ele passa por eles" (p. 65), ou seja, esse olhar é uma "segunda abertura" (p. 65). Portanto, através dessa "abertura que sou, ele é um ponto de interrogação com relação à esfera solipsista, é a possibilidade de uma distância entre o nada que sou e o ser" (p. 65).

O problema do outro se reduz à possibilidade de que o outro se apresente como um outro foco de negatividade; "o outro nasce $a$ meu lado, por uma espécie de broto ou de desdobramento” (p. 65), onde se coloca a questão: como discernir e conceber um nada de outrem? Essa interrogação demonstra que esquecemos que o nada não é e ao mesmo tempo sendo revelado pela nega-intuição é que apreendemos o seu próprio inverso, porque haverá vários seres e assim haverá, do mesmo modo, tantos nadas.

A questão principal aqui não é saber como discernir um nada de outro, "pois dizer que não sou nada no sentido da identidade é dizer que sou em sentido ativo meu corpo e minha situação" (p. 66), mas a questão que envolve por detrás desse discernimento é o 
de saber se pode existir mais do que um corpo e, também, se pode existir mais do que uma situação.

Por mais que eu chegue a pensar completamente o não-ser de meu não-ser, concordaria que, para ser verdadeiramente nãoser, este não-ser deveria renunciar em proveito do que sou completamente ou de fato. Nesse sentido, diante da reflexão, não posso, simplesmente, vangloriar-me de participar de um "pensamento do mundo que seja idealmente o mesmo" (p. 67). Porque estou fora, na superfície e na volubilidade do ser visível, em que sou carne, em que há outra coisa, um outro que não é um mero objeto qualquer do mundo.

No entanto, eu o sou. E o que eu chamo ser o engloba num "olhar vindo de parte alguma e que, entretanto me envolve, a mim e à minha potência de ontogênese, de todos os lados" (p. 67). Sobre essa experiência do olhar do outro sobre mim nada mais "faz do que prolongar a minha convicção íntima de não ser nada” (p. 68), de acreditar que apenas vivo como parasita do mundo, "habitando um corpo e uma situação” (p. 68).

Sabemos que uma "filosofia rigorosa de nega-intuição explica os mundos privados sem fechar-nos neles" (p. 68); essa mesma filosofia ensina que não há propriamente intermundo, porque cada espectador habita apenas o seu lugar, ele compreende somente seu ponto de vista.

E entra no ser apenas por meio da sua situação; mas porque não é nada e sua relação com sua situação e seu corpo é uma relação de ser, sua situação, seu corpo, seus pensamentos não interpõem uma tela entre ele e o mundo; são, ao contrário, os veículos de uma relação com o ser, na qual terceiros podem intervir. (Merleau-PonTy, 1971, p. 68)

Por outro lado, a filosofia da consciência ou da reflexão, "só pode justificar a fé perceptiva na unicidade do mundo reduzindo-a à consciência da identidade do mundo" (p. 68) e, desse modo, fazendo da ilusão uma mera privação. 
$\mathrm{Na}$ filosofia reflexionante, ao contrário, esse processo de compreender como uma consciência constituinte é vista por uma outra que seja sua igual e, portanto, também constituinte - e por isso, imediatamente, faz-se mister que a primeira passe a ser constituída. A dificuldade desse reconhecimento recíproco reside "em que uma e outra são concebidas como atos centrífugos, sínteses espirituais, e não se vê como poderiam refluir em direção à sua origem" (p. 68). Ao contrário, numa filosofia do negativo, "a própria definição do ipse significa aderir a uma situação de fato ou mantê-la como vínculo com o ser" (p. 68).

Admite-se que o nada se destina ao ser, então, "minha presença como nada é uma exigência de totalidade, de coesão” (p. 69). Nesse sentido, trata-se do mesmo ser: "tudo o que é parcial há de ser reintegrado, toda negação é, na realidade, determinação, e o ser-si e o ser-outro, e o ser-em-si são fragmentos de um único ser” (p. 69).

O que Merleau-Ponty quer demonstrar é que todo o movimento do ser e do nada aparecem como cumplicidade, numa espécie de equivalência e que o "negativismo, se for rigoroso, absoluto, é uma espécie de positivismo” (p. 69). Vejamos o célebre problema ontológico de Leibniz, por que há algo ao invés de nada. Ora, o que Leibniz quer é colocar, por um instante, o nada perante o ser, mas tal recuo para aquém do ser, tal evocação de um nada possível, é, para Merleau-Ponty, como que uma prova pelo absurdo, que, no fundo, aparece como a produção soberana do ser por si próprio. Esse problema desaparece com a alternativa: o nada não existe e o ser existe, e eles se ajustam um no outro. Quando se pensa no negativo, tudo é escuro, nebuloso; quando se pensa como negativo, tudo é claro. Isso que dizer que o que chamamos de negação e o que chamamos de posição revelam que são cúmplices ou até uma certa espécie de igualdade, de cumplicidade entre eles, é dizer que eles são o mesmo lado da moeda.

O ser e o nada vagueiam num "tumulto ao silêncio semelhante", no qual a amplitude do ser sobrepujará o nada, e nem mesmo o balbuciar do mundo irá desvelar o seu silêncio, percor- 
rendo em mim a presença originária do entrar em si e do sair de si que são idênticas. No pensamento do negativo, a "nega-intuição do nada é a atitude filosófica que põe a reflexão e a espontaneidade numa espécie de equivalência” (p. 70).

Segundo Merleau-Ponty, "para quem pensa o negativo em sua pureza” (p. 71), isto não consiste em dois movimentos - o abandono ao mundo e a retomada reflexionante -, também não admite duas atitudes: uma natural e a outra filosófica. A primeira, de atenção às coisas, e a segunda, de atentado à significação das coisas. Mas "cada uma pondo como que de reserva a possibilidade de transformar-se na outra; há uma percepção do ser e uma impercepção do nada que são coextensivas uma à outra, identificando-se (p. 71). "Ou seja", é a mesma coisa dizer que o nada não é e dizer que há apenas o ser (p. 71); “em suma”, que não se poderia encontrar o nada entre as coisas que são, como uma dentre elas (p. 71).

Quando se pensa o negativo além do problema da atitude natural e da atitude filosófica numa espécie de equivalência, que são coextensivas uma à outra, entre uma percepção do ser e uma impercepção do nada, demonstra-se que o pensamento do negativo é "invulnerável, porquanto também é pensamento da possibilidade absoluta, de sorte que já contém tudo o que poderíamos opor-lhe” (p. 71). Mas esse pensamento rigoroso do negativo só "começa opondo absolutamente o ser e o nada e termina mostrando que o nada é, de algum modo, interior ao ser, sendo este o único universo" (p. 71).

A crítica de Merleau-Ponty aponta dois movimentos: primeiro, "aquele pelo qual o nada chama o ser" e, segundo, "aquele pelo qual o ser chama o nada” (p. 72). Esse entrelaçamento entre ambos não se confunde, uma vez que sua relação é de cruzamento. No primeiro aspecto, o ser é negação da negação, ele possui uma infraestrutura de nada, ele é atributo do conhecimento. Nesse caso, “o ser é considerado do ponto de vista do nada” (p. 72). No segundo aspecto, o nada é posição reiterada, ou seja, posição da posição, ele 
possui uma infra-estrutura de ser, e o conhecimento é atributo do ser. $O$ nada é visto, então, sobre o sentido do ser.

Ao aproximar o pensamento do negativo puro, Merleau-Ponty mostra que eu, que me interrogo sobre o ser, não sou nada, ele circunscreve-se, "por meio desse enunciado, uma antinatureza que sou eu: sou o que não possui natureza, sou um nada” (p. 72). Desse modo, estabeleço que o nada não é, e que o não-ser é de certa forma ser, "que é globalmente não-ser, [...] se condena a definir o ser como plenitude e proximidade absolutas, estabelece que o ser é” (p. 72).

Aquele que interroga e nomeia - o filósofo -, este nada que é, demonstra uma certa fissura no ser, que por si só "já é uma variante do princípio de identidade que define o ser” (p. 72). A primeira crítica que Merleau-Ponty faz com relação ao pensamento do negativo puro é

pensando a partir do negativo puro, já se decide pensar segundo a identidade, já se está na identidade, pois esse negativo que nada pode limitar em seu gênero, devendo ir ao termo de si mesmo, também será profundamente negação dele mesmo, e se pronunciará sob a forma de um advento do ser puro. (Merleau-Ponty, 1971, p. 72-73)

Por mais que seja relevante esse pensamento do negativo puro, cairíamos numa armadilha se afirmássemos que é, destruiríamos sua negatividade. Mas, se simplesmente afirmássemos que não é, por outro lado, cairíamos numa espécie de possibilidade, concedendolhe uma espécie de ser, já que ele é nada. Merleau-Ponty prossegue sua crítica ao pensamento negativista afirmando:

Um pensamento negativista é do mesmo modo um pensamento positivista, e nessa reviravolta permanece o mesmo, no seu propósito de, considerando o vazio do nada ou o pleno absoluto do ser, ignorar em todo caso a espessura, a profundidade, a pluralidade de planos, os segundos-mundos. (MERLEAU-PONTY, 1971, p. 73) 
Mesmo que tudo isso pareça estranho, é mister dar razão ao pensamento negativista quando ele afirma que o negativo puro chama o ser puro.

Mas, visto que a negação pura unicamente só existe em princípio, e o para-si "existente é estorvado por um corpo que não está fora se não estiver dentro, que se interpõe entre si e si próprio - ao passo que o ser puro também é inencontrável” (p. 73), então, para que esse ser seja positivo e pleno, "deve ser plano, permanecendo, pois, o que é, para além da ambivalência onde estamos confinados" (p. 73). Uma outra aproximação que Merleau-Ponty faz é que o pensamento do negativo puro ou do positivo puro seja, pois, um pensamento de sobrevôo, "que opera sobre a essência ou a pura negação da essência, sobre termos cuja significação já foi fixada e que mantém em sua posse” (p. 74).

Por conseguinte, o pensamento negativista ou positivista reencontra o mesmo postulado da filosofia reflexionante, segundo o qual "nenhum resultado da reflexão pode retroativamente comprometer quem o opera nem alterar a idéia que fazíamos dele" (p. 75). Por isso, não pode ser de outra maneira, isto é, se partimos do negativo puro, "ele nunca admitirá nada nele e, ainda que nos apercebamos que precisa do ser, somente precisará dele como vizinhança distante que não o altera” (p. 75). Como sempre, nunca tenho o ser como é, só o possuo interiorizando-o, pois é a própria ambivalência, ou seja, a contradição absoluta. Aquele que desmente ou afirma o que é e o que não é cai na inerência do ser ao nada e do nada ao ser e, ao mesmo tempo, reduz o seu sentido de "espetáculo" (p. 80).

Merleau-Ponty faz um paralelo entre as características abstratas de um pensamento do negativo puro ou do positivo e a experiência da visão "como nadificação" (p. 80). Segundo Merleau-Ponty, a experiência da visão, não é uma visão do panorama que temos das coisas ou do mundo, mas o que ela exprime é o invisível do mundo, pelo qual encontro as coisas e o mundo, lá onde eles estão. Já que o olho vê o mundo e, assim como ele, o habita como o homem habita 
sua casa (Merleau-Ponty, 1969, p. 49). Não existe uma visão pura, totalizante e completa, que possa oferecer a ilusão de ver, de ter à distância, onde se ver "é não ser e se o que é visto é o ser" (MerleaUPONTY, 1971, p. 80). Temos sim uma visão normal, que é presença imediata no mundo e que procura seu ponto de apoio nas coisas vistas, pois ver jamais é nadificar. Porque aquilo o que vejo e o que eu que vejo fazem parte da mesma abertura, e a relação não é de contradição entre eles, mas é imediata e até frontal com aquilo que meu olhar me chama. Por conseguinte, "as coisas chamam meu olhar, meu olhar acaricia as coisas, sente seus contornos e seus relevos, entre ele e elas vislumbramos uma cumplicidade” (p. 80).

Dessa forma, a visão não é a relação imediata do para-si com o em-si, pois somos convidados a redefinir tanto aquele que vê quanto o mundo visto, e assim o olhar do filósofo é um nascimento inacabado.

A analítica do Ser e do Nada é aquela que vê esquecendo-se de que possui um corpo e de que aquilo que vê está sempre sob o que vê, tentando forçar a passagem em direção ao ser puro e ao nada puro, na medida em que se instala na visão pura, que se faz visionário, mas que é remetido à sua opacidade de vidente e à profundidade do ser. (Merleau-Ponty, 1971, p. 81)

Nesse sentido, o mundo sensível e histórico é intermundos, tendo em vista que eles são solidários uns com os outros, pois é através deles que vivemos, vemos e fazemos. É nas nossas vistas que os registros se inscrevem como sendo coisa, mundo e história.

A filosofia da negatividade não elucida a fé perceptiva, já que ela coloca no princípio de sua investigação o nada enquanto nada e, ao mesmo tempo, o ser enquanto ser pensa que o saber do nada é um nada de saber e que o nada unicamente é acessivel sob formas bastardas, incorporadas ao ser. Essa filosofia do negativo, então, pratica um pensamento essencialista "que se refere a significações além da experiência”, e assim ela constrói "nossas relações com o 
mundo" (p. 88). A filosofia da negatividade simplesmente identifica os princípios opostos:

Justamente porque o nichtiges Nichts não é, o há reserva-se a um ser sem mistura, positivo, pleno, justamente porque não há idéia do nada, o nada nadifica livremente enquanto o ser é. Justamente porque a transcendência é acesso a um Ser e fuga de Si, essa força centrífuga e impalpável que somos nós preside a toda aparição do Ser, sendo a partir do Si, por ekstase ou alienação, que se produz o "há". (Merleau-Ponty, 1971, p. 89)

Desse modo, a filosofia do negativo deixa uma espécie de mal-estar, porque "ela descreve nossa situação de fato com uma acuidade jamais levada a cabo” (p. 89) e, no entanto, nos fica a simples impressão de que nossa situação foi sobrevoada e o é de fato: "quanto mais se descreve a experiência como mistura do ser e do nada, mais se confirma sua distinção absoluta, quanto mais o pensamento adere à experiência, mais ele a mantém à distância” (p. 89). O ponto de partida de Merleau-Ponty não será: o ser é e o nada não é e nem tampouco só há o ser que aparece como fórmulas de um pensamento totalizante ou de um pensamento de sobrevôo. Mas o ponto de partida dessa "nova ontologia" (p. 166) é: "há o ser, há o mundo, há alguma coisa, há coesão, há sentido” (p. 90). Tratase de compreender esse logos na sua presença originária, onde ele "se pronuncia silenciosamente em cada coisa sensível" (p. 194) e que esse mesmo logos, ao ser proferido, seja mantido inteiro e que o ser percebido sublima uma relação carnal com o mundo. Ora, é através da pergunta primordial o que há? que a presença se realiza na filosofia, como uma reflexão em que as articulações de um só tecido abrem uma polaridade do logos a uma noção da carne, desvelando assim o desdobramento de uma interrogação.

Numa nota de fevereiro de 1960, Merleau-Ponty mostra bem a diferença entre seu pensamento e o pensamento sartriano e explica a razão de seu desacordo: 
Em Sartre sou sempre eu que faço a profundidade, que a cavo, que tudo faço e me fecho dentro da minha prisão. Para mim, ao contrário, mesmo os atos caracterizados, a decisão (a ruptura de um comunista com o Partido), não é um não-ser que se faz ser ( ser comunista ou ser não-comunista). Estas decisões que cortam são ambíguas para mim [...] e essa ambigüidade [...] é do mesmo tipo que a imparcialidade da história passada, quando coloca as nossas escolhas antigas ou as doutrinas antigas para além do verdadeiro e do falso. Para mim a verdade é este além da verdade, esta profundeza onde existem ainda diversas relações a considerar. $\mathrm{O}$ gradiente: não o ser linear, mas o ser estruturado. (Merleau-Ponty, 1971, p. 217)

Para desvelar a abertura do ser, Merleau-Ponty irá "substituir a intuição do ser e a nega-intuição do nada por uma dialética” (p. 91).

A dialética, no sentido em que Merleau-Ponty a concebe, não pode ser vista como a "recusa do pensamento de sobrevôo" (p. 93). Essa dialética tem de ser operada ou trabalhada no ser; ela é o pensamento do ser-visto como manifestação de si que desvenda fazendo-se. A dialética é tudo aquilo que de tal modo "nunca pôde formular-se em tese sem desnaturar-se e, se pretendermos conservarlhe o espírito, talvez seja mesmo preciso não nomeá-la” (p. 93).

A tarefa da dialética, como pensamento de situação e até mesmo como pensamento em contato com o ser, será de saracotear as falsas evidências, bem como será de "denunciar as significações cortadas da experiência do ser, esvaziadas, e criticar-se a si mesma na medida em que se venha a tornar uma delas" (p. 93).

Merleau-Ponty faz uma distinção entre uma boa e uma má dialética, em que a boa dialética é hiperdialética. Segundo ele, a má dialética é a que "não quer perder sua alma para salvá-la, que quer ser dialética imediatamente" por isso, "torna-se autônoma e termina no cinismo, no formalismo, por ter evitado seu próprio duplo sentido" (p. 95). Dessa forma, a má dialética acredita "recompor o ser usando um pensamento tético, com um conjunto de enunciados, com tese, antítese e síntese" (p. 96). Enquanto a boa dialética, aquela 
que sabe que "toda tese é idealização, de que o Ser não é feito de idealização ou coisas ditas” (p. 96), e que, por conseguinte, é preciso rejeitar ou negar não só a idéia da superação que reúne os conceitos filosóficos. É "a idéia de que ela redunde num novo positivo, numa nova posição” (p. 96). Do mesmo modo que Merleau-Ponty nos fala da sobre-reflexão, ele nos fala também de uma hiperdialética. A hiperdialética é um pensamento que encara sem restrição à pluralidade das relações e às ambigüidades dessas relações.

O conceito de hiperdialética concerne à expressão mesma do movimento que a vida do homem revela numa experiência em que obtém o seu próprio lugar, a sua morada e que reconheça o solo no qual se encontra. O que Merleau-Ponty exclui da dialética é a simples idéia do negativo puro, e o que devemos desvelar, sem dúvida, é uma dialética do ser. E essa idéia não pode ser nem o ser para-si nem o ser em-si. Porque essas são definições frágeis e lábeis e que nos podem levar uma à outra, e "que deve reencontrar o ser antes da clivagem reflexiva, em torno dele, no seu horizonte, não fora de nós e não em nós, mas onde os dois movimentos se cruzam, onde 'há' alguma coisa” (p. 96).

Essa hiperdialética, que atende na abertura do duplo movimento da coisa mesma, é reconhecida, agora, em um só movimento, onde há alguma coisa, onde há simplesmente abertura.

\section{CONSIDERAÇÕES FinAIS}

O problema da negatividade é o problema da profundidade, afirma Merleau-Ponty. Sartre fala de um mundo que é, não vertical, mas em si, ou seja, plano, e de um nada que é abismo absoluto. Nele não há profundidade porque a profundidade é sem fundo. Vimos que, para Merleau-Ponty, o negativo nada quer dizer, e o positivo também não, pois eles são sinônimos. Para Merleau-Ponty, seu ponto de partida está onde Sartre tem seu ponto de chegada, isto é, no ser retomado pelo para-si. "Este é seu ponto de chegada porque ele parte do ser e da negatividade e constrói sua união” 
(Merleau-Ponty, 1971, p. 216). Nesse sentido, assinala Merleau-Ponty, o ser e o nada são duas propriedades abstratas.

Construir a transcendência, ela existe de início, como Ser forrado de nada, e o que há a explicar é o seu desdobramento (coisa, aliás, jamais feita) - Descrever a estrutura, tudo está aí, e a integração das estruturas no Sem, e o sentido como sentido de investimento (o sentido da palavra que digo a alguém lhe cai em cima, toma-o, antes de ele ter compreendido, arrancalhe a resposta - Estamos na humanidade como horizonte do Ser, porque o horizonte é aquilo que nos rodeia a nós não menos do que às coisas. Mas é o horizonte, não a humanidade, que é o ser - Como a humanidade (Menschheit), todo conceito é, de início, generalidade de horizonte, de estilo - Não existe mais problema do conceito, da generalidade, da idéia quando se compreende que o próprio sensivel é, invisível, que o amarelo é capaz de erigir-se em nivel ou horizonte. (MERLEAu-PonTY, 1971, p. 216-217)

A questão que a filosofia da negatividade coloca para nós, com relação ao sentido do que seja o mundo, é que ela "não pretende saber se o mundo existe verdadeiramente ou se é apenas um sonho bem articulado" (p. 96-97).

Essa questão recobre outras, supõe conhecidos, e melhor conhecidos, o sonho, a imagem, ela interroga o mundo em nome de uma pretensa possibilidade do psíquico, lança sobre ele a sombra de uma inexistência possivel, mas não ilumina a existência mental que põe em seu lugar, concebendo-a, na verdade, como uma existência real enfraquecida ou degradada, e se a dúvida assim compreendida fosse superada por algum argumento, a existência real que seria atribuída a nossos sonhos seria a mesma, obscura e incompreensível, de onde partiríamos, e tudo recomeçaria. (Merleau-Ponty, 1971, p. 97)

Por isso, diz Merleau-Ponty, nunca perguntamos se o mundo existe, mas sim perguntamos o que é, para o mundo, existir. 
Posta assim, a questão não é radical. Parece que, ao perguntarmos o que é existir para as coisas e para o mundo, caminhamos para uma definição em que é possível entendê-la, num sentido superficial, ao problema da palavra. "Afinal, as questões acontecem na linguagem” (p. 97). E é com a linguagem que devemos desvelar a reflexão filosófica sobre o mundo; e, em busca da resposta a essa questão, ela só é possível de ser procurada nas significações das palavras, visto que é com as palavras que a questão pode ser entendida e ser respondida na sua abertura do mundo, em busca das coisas elas mesmas.

Merleau-Ponty nos ensinou que a filosofia não é um léxico e que não se interessa pelas significações das palavras tal como o poeta na palavra ou o lógico no enunciado. A filosofia não "procura substituto verbal para o mundo que vemos, não o transforma em coisa dita”, ela não se "instala na ordem do dito ou do escrito". Mas que "são as próprias coisas, do fundo de seu silêncio, que deseja conduzir à expressão” (p. 16). Não podemos conduzir a filosofia simplesmente a uma "análise lingüística” (p. 97). E é justamente isso que os lingüistas nos ensinaram:

[...] que a significação unívoca é apenas uma parte da significação da palavra, que há sempre, além, uma auréola de significação que se manifesta em modos de emprego novos e inesperados, que há uma operação da linguagem sobre a linguagem [...] fazendo da própria significação da palavra um enigma. Longe de deter o segredo do ser do mundo, a linguagem é, ela mesma, um mundo, ela mesma, um ser - um mundo e um ser de segunda potência, já que não fala no vazio, fala do ser e do mundo, redobrando, pois, seu enigma, em vez de fazê-lo desaparecer. (Merleau-PonTy, 1971, p. 97-98)

A interrogação filosófica sobre o mundo não faz do próprio mundo aquilo que dele dizemos, ela, portanto, reitera no interior da linguagem. $O$ ato de filosofar não é um ato de contestar o universo das coisas ditas, das coisas brutas "como se o mundo efetivo 
fosse um cantão da linguagem, a percepção, uma palavra confusa e mutilada, a significação das palavras, uma esfera de possibilidade perfeitamente segura” (p. 98). A linguagem não é um lugar privilegiado, mas é verdadeiramente o lugar no qual a questão sobre o mundo está posta à interrogação filosófica. Essa mesma interrogação sobre o mundo "não pode, por exemplo, consistir em contestar o mundo em si ou as coisas em si em proveito de uma ordem dos fenômenos humanos” (p. 98), ou seja, ela não pode contestar a ordem "do sistema coerente das aparências tal como podemos construí-lo, nós os homens, sob condições de fato que são as nossas” (p. 98).

Sendo assim, portanto, como alcançar esse campo de investigação, visto que ele situa-se no campo da linguagem? Só o podemos atingir quando o filósofo perguntar-se a si mesmo se esse campo é fechado e se ele basta a si mesmo. Deve perguntar se ele não se abre, como artefato. Ou se ele "concerne ao ser-verificado, ao serasseverado, ao ser convertido em objeto, não tem um horizonte de ser bruto e do espírito bruto de que os objetos construídos e as significações emergem e que não explicam” (p. 98). A interrogação filosófica ao interrogar o ser bruto, o espírito bruto como abertura do mundo, como entrelaçamento entre ser e mundo, torna-se radical. Ela só é radical em face de nossa admiração diante do mundo percebido, no qual o mundo não "seria mais do que a sombra: a sombra está em nós antes de estar fora [...], nada encontraríamos que ultrapasse ou apenas iguale ou explique a solidez do mundo sob nossos olhos e a coesão de nossa vida nele” (p. 99), como solo e cepa de nossa vida.

Ao enunciar essa nossa admiração como sendo a abertura mesma da filosofia, sendo essa abertura do ser-no-mundo, MerleauPonty dirá que a filosofia não deve ser compreendida como ruptura e nem mesmo como coincidência com o mundo e, a um só tempo, essa relação não é nunca alternância e nem coincidência da ruptura. Pois essa abertura tem como desejo um certo desvelar de nossa 
condição de ser humano, de ser-no-mundo como horizonte, visto que estamos instalados nele.

A filosofia não busca, simplesmente, analisar nossa relação com o mundo, desfazendo-o para, logo em seguida, reconstruí-lo. Ela o interroga sempre, ela o retoma para repetir "sua cristalização diante de nós” (p. 101). De tal maneira que essa cristalização, de uma parte, "nos é dada inteiramente feita, de outra não está nunca acabada, e podemos ver por aí como o mundo se faz" (p. 101).

Nesse sentido, a filosofia necessita definir o seu próprio estatuto filosófico para sair dos embaraços de noções feitas, tais como as noções de sujeito e de objeto. Só assim a filosofia, ao ter se libertado de noções preestabelecidas, irá descobrir sua tarefa primordial, que é "saber o que é o mundo e o que é o ser" (p. 101).

A filosofia, como interrogação, não é um privilégio do filósofo para questionar o conhecimento, pois, para este, "o ser e o mundo não são incógnitas que se trata de determinar por suas relações com os termos conhecidos" (p. 101). E nem tampouco como uma tomada de consciência, já que, para a filosofia, "não se trata de reencontrar numa consciência legisladora a significação que teria dado ao mundo e ao ser graças a uma definição nominal” (p. 101102).

Do mesmo modo que não falamos por falar, que falamos a alguém de alguma coisa ou de alguém e que, nessa iniciativa da palavra, está implícita uma visão do mundo e dos outros da qual tudo o que dizemos está suspenso. (Merleau-Ponty, 1971, p. 102)

Merleau-Ponty revela num primeiro momento um certo paradoxo no qual o ser bruto, objeto da interrogação filosófica, jamais será um objeto da questão filosófica, uma vez que, ao abordar a questão da profundidade e a noção de distância na interrogação filosófica, que lhes são essenciais, elas escapam de uma obturação completa, visto que não questionamos o mundo pelo olhar do ser selvagem. Por esse motivo, nunca o vazio atingiu tanta ressonância, 
no qual "não é um nada que o ser pleno viria obturar, mas a questão atribuída ao ser poroso” (p. 102), que a interrogação filosófica questiona "e do qual não obtém resposta, mas confirmação de seu espanto” (p. 102). Em outros termos, diz ele: devemos compreender a "percepção como esse pensamento interrogativo que deixa ser o mundo percebido em vez de pô-lo, diante do qual as coisas se fazem e se desfazem como uma espécie de deslizar aquém do sim e do não” (p. 102).

A partir desse primeiro paradoxo, é preciso anunciar um outro, em que a filosofia "se distingue de todo problema de conhecimento e proíbe que se fale em filosofia de solução: aproximação do longínquo como longínquo, a filosofia também é questão levantada àquilo que não fala” (p. 102).

Antes que a interrogação filosófica pergunte à nossa experiência primordial do mundo o que é o mundo, é mister interrogar o mundo "antes que seja coisa de que se fale e antes que seja reduzido a um conjunto de significações manejáveis, disponíveis” (p. 102). Deve desvelar a questão que está em nossa vida muda, deve endereçar-se a essa mistura do mundo, onde a filosofia possa encontrar regressando ao que ela diz e que esse regresso nos remeta à reflexão, "porque o exame das significações em si mesmas nos daria o mundo reduzido às nossas idealizações e à nossa sintaxe” (p. 102).

A filosofia não está carregada por uma certa magia das palavras, nem sempre as palavras dizem necessariamente o modo de ser, elas "revelam mais estreitamente a vida do todo e fazem vibrar as nossas evidências habituais até desjuntá-las" (p. 103). O mais importante é saber se a filosofia como abertura ao mundo, desvela o ser bruto ou selvagem, na medida em que a filosofia, enquanto questão mesma, possa realizar, por meios da linguagem, um uso que lhe possa igualar-se no que ela quer dizer, revelar a vida, a história e o mundo.

A interrogação filosófica não recebe uma resposta que possa satisfazer a uma questão proposta, pois o "mundo existente existe 
sob a forma de interrogativa", em que "a filosofia interroga a fé perceptiva” (p. 103). Na medida em que

a filosofia é a fé perceptiva interrogando-se sobre si mesma, pode-se dizer dela, como de toda fé, que é fé porque é possibilidade de dúvida e esse infatigável percurso das coisas, que é nossa vida, também é uma interrogação contínua. (MERLEaUPONTY, 1971, p. 103)

Isto é, "não é só a filosofia, no início é o olhar que interroga as coisas" (p. 103).

Quando a interrogação filosófica coloca em questão o próprio desenrolar de nossa vida "não é porque um não-ser central ameaça a cada instante revogar seu consentimento no ser" (p. 103), mas sim porque "nós mesmos somos uma única questão contínua, uma empresa perpétua de marcação de nós mesmos sobre as constelações do mundo e das coisas, sobre nossas dimensões" (p. 103-104).

A questão fundamental que é colocada a nu pela filosofia é onde estou?, que horas são?

De um momento para o outro, um homem ergue a cabeça, respira fortemente, espreita, considera e reconhece sua posição: pensa, suspira e, tirando seu relógio do bolso que se aloja de encontro à costela, olha as horas. Onde estou? e Que horas são? Essa a questão inesgotável que propomos ao mundo... (Merleau-Ponty, 1971, p. 104)

Certamente, toda questão que é abordada pela interrogação filosófica faz um "apelo à totalidade ao qual nenhum ser objetivo dá resposta” (p. 104). Justamente porque a linguagem está em

busca de sua própria reflexão e de sua própria instituição, que a interrogação apodera-se do filósofo, como do poeta ou do pintor, para reconhecer, com eles, diante da estranheza de seus poderes em recompensa de uma dupla desapossessão das coisas e de si. (Merleau-Ponty, 1971, p. 104) 
Essa mesma interrogação visa revelar: a percepção, a expressão, a comunicação, o mundo da vida, a sociedade ou a história. Pois o ser "é aquilo que exige de nós criação para que dela tenhamos experiência” (p. 187). Através da interrogação filosófica, pelo menos, podemos ver que a nossa vida é encarnada, e não há motivo algum para acreditar num espírito do mundo, que pudesse explicar ou operar em nós sem nós, além do mundo percebido. Aqui a interrogação filosófica é o espírito do mundo que somos nós, mas, para que isso ocorra, é preciso, desde de já, saber mover-nos e saber olhar em torno de nós.

MERLEAU-PONTY AND THE PHILOSOPHY OF NEGATIVITY IN THE VISIBLE AND THE INVISIBLE

Abstract: The article has as goal to describe Merleau-Ponty's criticism on the philosophy of negativity, especially in his work The visible and the invisible (1964). This critical is addressed mostly to the philosopher Jean-Paul Sartre (1905-1980).

Key words: Reflection, philosophy of negativity, ontology, dialectic.

\section{Referências}

Merleau-Ponty, M. Sinais. Tradução de Fernando Gil. Lisboa: Minotauro, 1962.

. O olho e o espirito. Tradução de Geraldo D. Barretto. Rio de Janeiro: Grifo Edições, 1969.

. O visivel e o invisível. Tradução de José Artur Gianotti e Armando M. d'Oliveira. São Paulo: Perspectiva, 1971.

. A natureza. Tradução de Álvaro Cabral. São Paulo: Martins Fontes, 2000.

SARTRE, Jean-Paul. L'être et le néant. Paris: Gallimard, 1943. 